\title{
A quantitative method to assess extrasynaptic NMDA receptor function in the protective effect of synaptic activity against neurotoxicity
}

\author{
C Peter Bengtson, Oliver Dick and Hilmar Bading*
}

Address: Department of Neurobiology, Interdisciplinary Centre for Neurosciences (IZN), University of Heidelberg, 69120 Heidelberg, Germany

Email: C Peter Bengtson - Bengtson@nbio.uni-heidelberg.de; Oliver Dick - Dick@nbio.uni-heidelberg.de;

Hilmar Bading* - Hilmar.Bading@uni-hd.de

* Corresponding author

Published: 24 January 2008

BMC Neuroscience 2008, 9:1 I doi:|0.||86/|47|-2202-9-1।
Received: 24 August 2007

Accepted: 24 January 2008

This article is available from: http://www.biomedcentral.com/I47I-2202/9/I I

(c) 2008 Bengtson et al; licensee BioMed Central Ltd.

This is an Open Access article distributed under the terms of the Creative Commons Attribution License (http://creativecommons.org/licenses/by/2.0), which permits unrestricted use, distribution, and reproduction in any medium, provided the original work is properly cited.

\begin{abstract}
Background: Extrasynaptic NMDA receptors couple to a CREB shut-off pathway and cause cell death, whereas synaptic NMDA receptors and nuclear calcium signaling promote CREB-mediated transcription and neuronal survival. The distribution of NMDA receptors (synaptic versus extrasynaptic) may be an important parameter that determines the susceptuibility of neurons to toxic insults. Changes in receptor surface expression towards more extrasynaptic NMDA receptors may lead to neurodegeneration, whereas a reduction of extrasynaptic NMDA receptors may render neurons more resistant to death. A quantitative assessment of extrasynaptic NMDA receptors in individual neurons is needed in order to investigate the role of NMDA receptor distribution in neuronal survival and death.
\end{abstract}

Results: Here we refined and verified a protocol previously used to isolate the effects of extrasynaptic NMDA receptors using the NMDA receptor open channel blocker, MK-80I. Using this method we investigated the possibility that the known neuroprotective shield built up in hippocampal neurons after a period of action potential bursting and stimulation of synaptic NMDA receptors is due to signal-induced trafficking of extrasynaptic NMDA receptors or a reduction in extrasynaptic NMDA receptor function. We found that extrasynaptic NMDA receptor-mediated calcium responses and whole cell currents recorded under voltage clamp were surprisingly invariable and did not change even after prolonged ( 16 to 24 hours) periods of bursting and synaptic NMDA receptor activation. Averaging a large number of calcium imaging traces yielded a small (6\%) reduction of extrasynaptic NMDA receptor-mediated responses in hippocampal neurons that were pretreated with prolonged bursting.

Conclusion: The slight reduction in extrasynaptic NMDA receptor function following action potential bursting and synaptic NMDA receptor stimulation could contribute to but is unlikely to fully account for activity-dependent neuroprotection. Other factors, in particular calcium signaling to the nucleus and the induction of survival promoting genes are more likely to mediate acquired neuroprotection. 


\section{Background}

Synaptic and extrasynaptic NMDA receptors are, respectively, coupled to survival and cell death pathways, which involves their opposing effects on the cAMP response element binding protein (CREB) [1-6] and their regulation of overlapping but distinct genomic programs recently revealed by a whole genome transcriptome analysis [7]. The differential role of NMDA receptors provides a new concept explaining how the same receptor, dependent on its location, can couple to both survival and death. This concept represents an alternative to the "Ca ${ }^{2+}$ load" hypothesis, which attempts to assign a toxic threshold to $\mathrm{Ca}^{2+}$ influx associated with NMDA receptor activation $[8,9]$. Precisely how NMDA receptors differentially regulate the activity of CREB or signaling molecules such as the extracellular signal-regulated kinases 1 and $2($ ERK1/2) is unknown, but differences in the NMDA receptor subunit composition and/or differences in signaling complexes associated with synaptic versus extrasynaptic NMDA receptors may be important $[5,10-13]$.

The toxic effects of extrasynaptic NMDA receptor activation can be counteracted to some extent by prior activation of synaptic NMDA receptors. For example, prolonged periods action potential (AP) bursting-induced with the $\mathrm{GABA}_{\mathrm{A}}$ receptor antagonist, bicuculline in cultured hippocampal networks robustly activates synaptic NMDA receptors, which protects against subsequent NMDAinduced excitotoxicity [14] as well as against pro-apoptotic stimuli such as serum deprivation [6] or staurosporine treatment [4]. Similarly, minor ischemic events or preconditioning systemic doses of NMDA are neuroprotective [15-19]. The neuroprotective effects of preconditioning neurons with low concentrations of NMDA are mediated, at least in cultured hippocampal networks, via AP-induced stimulation of synaptic NMDA receptors [20]. The molecules responsible for synaptic NMDA receptorinduced survival represent potential clinical targets to reduce neuron loss associated with pathological conditions including stroke and neurodegenerative diseases in which NMDA receptor-mediated excitotoxicity has been implicated [21-27].

NMDA receptor-mediated neuroprotection appears to involve multiple players including nuclear $\mathrm{Ca}^{2+}$ signaling, CREB, nuclear factor kappa B, ERK1/2, Akt1, phosphatidylinositol 3-kinase, protein kinase $C$ epsilon, and brainderived neurotrophic factor $[6,15-17,19,28,29]$. Given the central role of extrasynaptic NMDA receptors in cell death, it is also conceivable that signal-induced changes in surface expression or function of this pool of receptors could profoundly affect the susceptibility of neurons to toxic insults. The surface expression of NMDA receptors (presumably both synaptic and extrasynaptic receptors) is dynamic, whereby receptor endocytosis, exocytosis, and lateral movement are strongly regulated by activity [3033]. The first step in determining whether changes in the relative distribution of NMDA receptors (synaptic versus extrasynaptic) are associated with and responsible for activity and NMDA receptor-induced neuronal survival, requires a method that allows the precise quantitative assessment of extrasynaptic NMDA receptor function in individual neurons.

Techniques for the identification of the extrasynaptic NMDA receptor pool in brain slices are emerging [34,35]. However, considerable advances have been made in isolating extrasynaptic NMDA receptor function in cultured neurons. Such studies have employed a protocol, which specifically blocks synaptic NMDA receptors with MK801. MK-801 is a use-dependent open channel NMDA receptor blocker, which enters the channel only after its activation but then becomes trapped inside the pore to "irreversibly" block the receptor as long as the receptor is not re-activated to release the blocker [36,37]. Extrasynaptic NMDA receptor-mediated currents have been measured in single neurons isolated in micro-island cultures after blocking autaptic synapses with MK-801 during synaptic stimulation [38]. Techniques for quantifying extrasynaptic NMDA receptor-mediated currents in cultures of neuronal networks have also been developed but the parameters necessary for use-dependent blockade of NMDA receptors require refinement. Mass activation of synaptic NMDA receptors in neuronal networks of hippocampal cultures can be achieved using the $\mathrm{GABA}_{\mathrm{A}}$ receptor antagonist, bicuculline, which initiates recurrent synchronous bursting $[4,5,39]$. MK-801 application during bicuculline-induced bursting in hippocampal cultures provides a use-dependent blockade of synaptic NMDA receptors allowing the extrasynaptic NMDA receptor population to be subsequently activated with bath applied NMDA $[13,40]$.

The aim of this study was to investigate the possibility that the known neuroprotection afforded by synaptic NMDA receptor activation is mediated by changes in the surface expression and/or function of extrasynaptically localized NMDA receptors. A method based on previously used protocols was refined and verified in order to isolate extrasynaptic NMDA receptors and quantify their function in individual neurons that are part of a complex neuronal network. We found a surprisingly small neuron-to-neuron variation in extrasynaptic NMDA receptor function. Overnight network bursting, stimulating synaptic NMDA receptors, led to a measurable but very small loss of extrasynaptic NMDA receptor function, which seemed dwarfed by the dramatic neuroprotective effect of this treatment. 


\section{Results \\ MK-80 I treatment in bursting networks effectively isolates the extrasynaptic pool of NMDA receptors}

To establish the necessary parameters to isolate extrasynaptic NMDA receptors in hippocampal cultures, we first examined the blockade of synaptic NMDA receptor evoked EPSCs by MK-801 during bicuculline-induced bursts of APs. The protocol is described in the methods section and schematically represented in Figure 1A. Both before and after the MK-801 blocking protocol EPSCs were measured at $+40 \mathrm{mV}$ in the presence of $1 \mathrm{mM} \mathrm{Mg}^{2+}$ as well as $\mathrm{GABA}_{\mathrm{A}}$ and AMPA receptor antagonists. These recordings were not feasible at negative holding potentials in the absence of $\mathrm{Mg}^{2+}$ due to the appearance of multiple NMDA receptor-mediated EPSCs evoked by single stimuli (data not shown). Although NMDA and AMPA components of EPSCs can be differentiated from each other, the continuous barrage of EPSCs in AP bursting cultures necessitated the blockade of AMPA receptors. CNQX always blocked all burst activity (Figure 1B) and was applied during the MK-801 washout period to ensure that synaptic NMDA receptors remained blocked. Under these conditions, MK-801 $(10 \mu \mathrm{M})$ application for 2 to $6 \mathrm{~min}$ encompassing 4 to 8 bursts was sufficient to reduce NMDA receptor-mediated evoked EPSCs to $19.9 \pm 8.2 \%$ of their control amplitude $(n=5$, Figure $1 C, D)$. Although such evoked EPSCs probably do not reflect the response of all NMDA receptor containing synapses in each cell, they represent a random subset of such synapses, most of which were blocked by brief MK-801 treatment during bicuculline induced bursting.

Having established the parameters necessary to selectively block synaptic NMDA receptors, we utilized this protocol to functionally quantify the entire extrasynaptic NMDA receptor pool in single neurons using simultaneous voltage clamp electrophysiology and fluorescent $\mathrm{Ca}^{2+}$ imaging. Synaptic NMDA receptors were blocked by MK-801 during bicuculline induced AP bursting in current clamp mode (Figure 2A,B). MK-801 was washed out of the bath in the absence of glycine as in the EPSC protocol however CNQX was replaced with TTX to block all AP-induced neurotransmitter release in pre-synaptic cells. Current and $\mathrm{Ca}^{2+}$ responses to a $30 \mathrm{~s}$ rapid bath perfusion $(6 \mathrm{ml} / \mathrm{min})$ of $100 \mu \mathrm{M}$ NMDA were then measured at a holding potential of $-71 \mathrm{mV}$ (including a $-11 \mathrm{mV}$ correction for junction potential) in $10 \mu \mathrm{M}$ glycine and in the absence of $\mathrm{Mg}^{2+}(\mathrm{n}$ $=19$, Figure 2C,D). The extrasynaptic NMDA receptor pool was measured in this manner in one cell per coverslip.

\section{Protective effects of AP bursting against NMDA toxicity}

As a first step towards analyzing a possible mechanistic link between extrasynaptic NMDA receptor function and acquired neuroprotection, we established conditions that promote neuronal survival. Hippocampal neurons were treated overnight with bicuculline, which induced recurrent bursts of APs that are associated with synaptic NMDA receptor-dependent $\mathrm{Ca}^{2+}$-transients throughout the neuron [3]. Neurons were subsequently challenged with NMDA $(20 \mu \mathrm{M})$ for $10 \mathrm{~min}$, which triggers excitotoxic cell death. In untreated cultures, $9 \pm 2 \%$ of cells showed condensed nuclei indicative of cell death; NMDA treatment increased this cell death to $47 \pm 2 \%$. In cultures that were pre-treated with AP bursting for $16 \mathrm{~h}$ before NMDA application, only $14 \pm 1 \%$ of the neurons showed condensed nuclei and were counted as dead. AP bursting for $16 \mathrm{~h}$ without subsequent NMDA treatment had no significant effect on cell death ( $8 \pm 1 \%$ of cells were dead) (all experiments at $37^{\circ} \mathrm{C}, 3$ coverslips per group repeated in 5 independent experiments, Figure 3). These results demonstrate that recurrent network AP bursting protects neurons from subsequent NMDA-induced cell death.

\section{$\mathrm{Ca}^{2+}$ responses to toxic NMDA treatment}

Since $\mathrm{Ca}^{2+}$ overload has been suggested as a trigger for cell death in ischemia and NMDA receptor activation $[8,41,42]$, we measured the $\mathrm{Ca}^{2+}$ load at the soma activated by this toxic 10 min treatment with $20 \mu \mathrm{M}$ NMDA at $37^{\circ} \mathrm{C}$ (Figure $4 \mathrm{~A}$ ) and compared it with hippocampal neurons that had been treated overnight (16-24 h) with bicuculline $50 \mu \mathrm{M}$ (to induce AP bursting) or $0.05 \%$ DMSO (vehicle) at $37^{\circ} \mathrm{C}$. $\mathrm{Ca}^{2+}$ levels at the NMDA response peak and at a time point $10 \mathrm{~min}$ after NMDA washout were slightly higher in spontaneously bursting and bicuculline-treated cultures when compared to the control group (control: $\mathrm{n}=250$ cells on 5 coverslips, spontaneously bursting: $\mathrm{n}=128$ cells on 2 coverslips; bicuculline: $n=316$ cells on 6 coverslips, Figure $4 B$ ). This indicates that prolonged synaptic activity resulting from AP bursting slightly increases the NMDA-induced $\mathrm{Ca}^{2+}$ entry and/or $\mathrm{Ca}^{2+}$ release from intracellular stores, which could be due to preloading of the endoplasmic reticulum and/or a reduced sequestration and removal of $\mathrm{Ca}^{2+}$ from the cytoplasm. Thus the mechanism of protection afforded by AP bursting does not involve a reduction in the $\mathrm{Ca}^{2+}$ load during this toxic NMDA insult or the initial recovery period thereafter.

\section{Isolated extrasynaptic NMDA receptor-mediated currents and $\mathrm{Ca}^{2+}$ signals are not affected by overnight AP bursting} Extrasynaptic NMDA receptors are coupled to a CREB shut-off mechanism and cell death pathways [4]. We reasoned that a specific reduction in extrasynaptic NMDA receptor numbers or function could underlie the AP bursting-induced protective effects. NMDA receptors are known to be endocytosed from extrasynaptic sites adjacent to post synaptic densities in mature dendritic spines $[33,43,44]$. In our cultures at the time point of recordings (11-12 DIV) spines are present (see Additional file 1). To 
A.

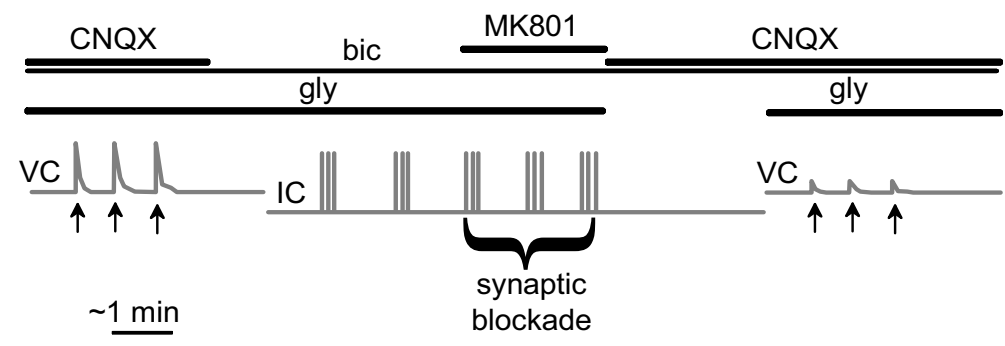

B.
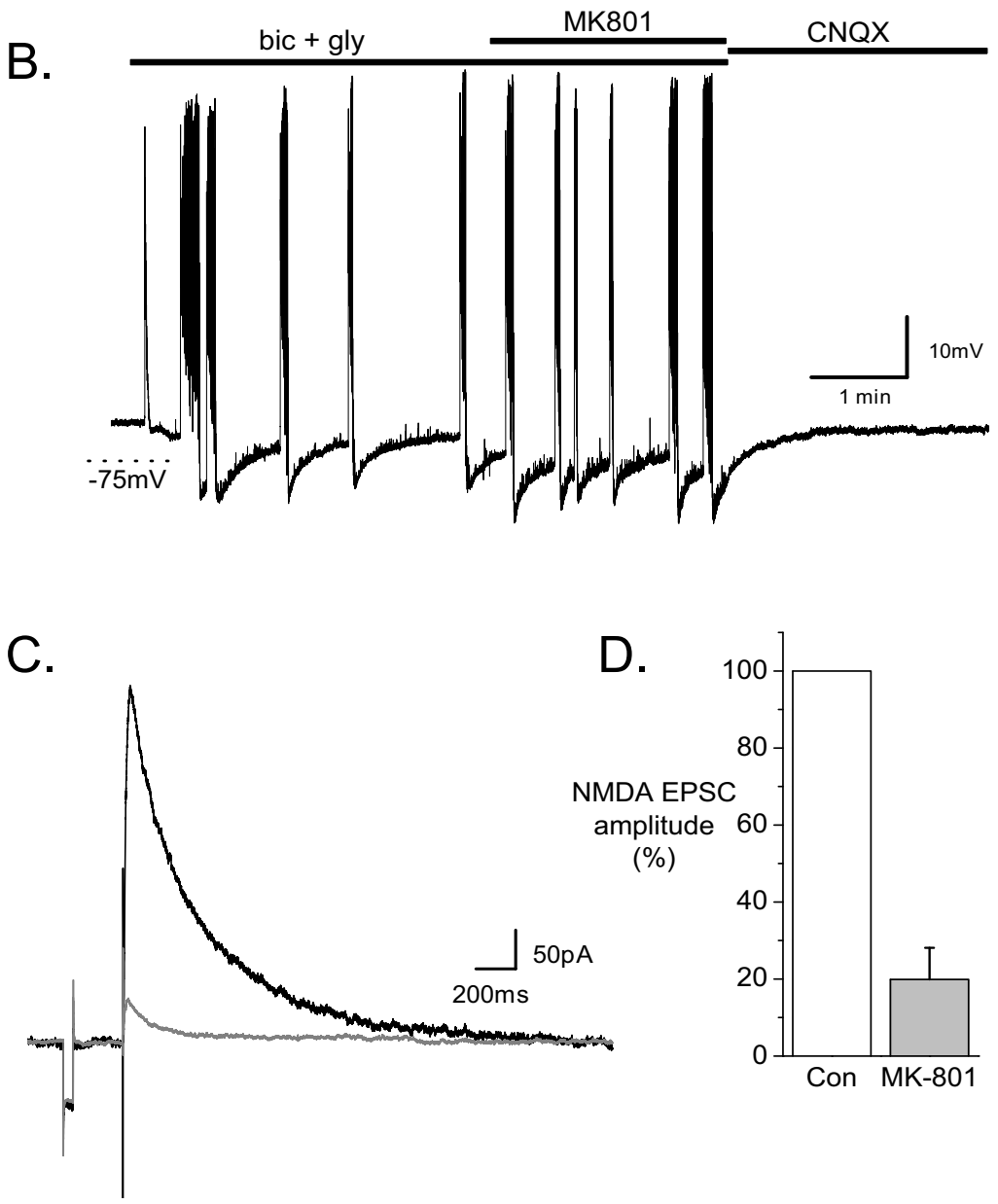

Figure I

MK-80 I effectively blocks synaptic NMDA receptors during bicuculline induced bursting. (A) The MK-80 I protocol used to selectively block synaptic NMDA receptors is shown schematically (see Methods). NMDA receptor-mediated EPSCs were evoked by single stimuli (arrows) and measured in voltage clamp mode (VC) at $+40 \mathrm{mV}$ in the presence of $10 \mu \mathrm{M}$ CNQX, $50 \mu \mathrm{M}$ bicuculline (bic) and $10 \mu \mathrm{M}$ glycine (gly). Following CNQX washout, bursting returned as was recorded in current clamp mode (IC) before $10 \mu \mathrm{M}$ MK80I was applied for 4 to 8 bursts (42 to I88 spikes, 2.2 to 6.2 min) to selectively block synaptic NMDA receptors (synaptic blockade). Bursting was then silenced in CNQX in the absence of glycine to prevent unblocking of NMDA receptors. EPSCs were recorded under the same stimulation parameters. (B) Representative recording from the IC component of the protocol. (C) NMDA receptor-mediated EPSCs recorded before (black trace) and after (grey trace) the MK80I protocol recording shown in B. (D) Cumulative data from 5 neurons showing the EPSC amplitude before (control) and after the MK-80 I protocol (MK-80I). Bars represent the mean and whiskers the SEM. 


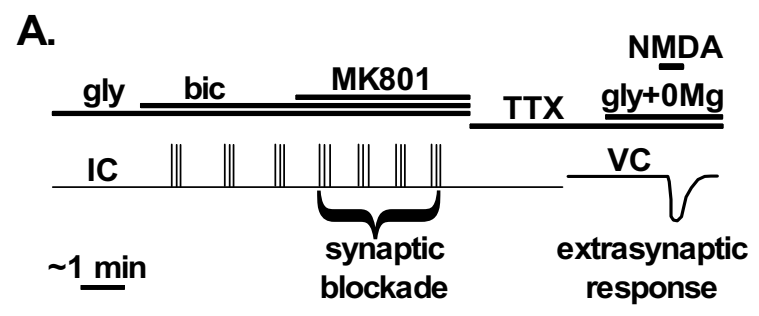

B.

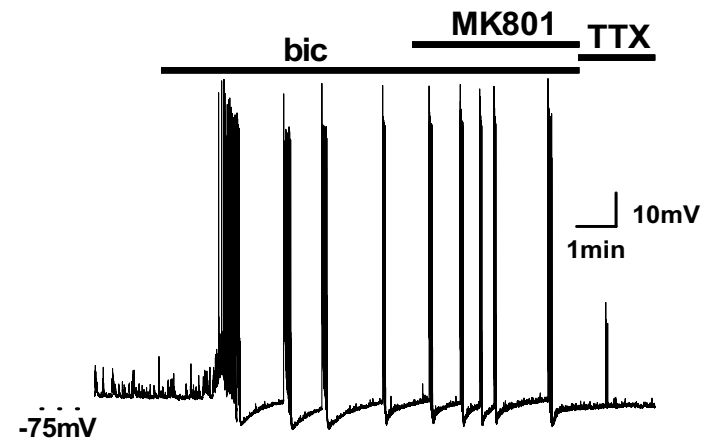

C.

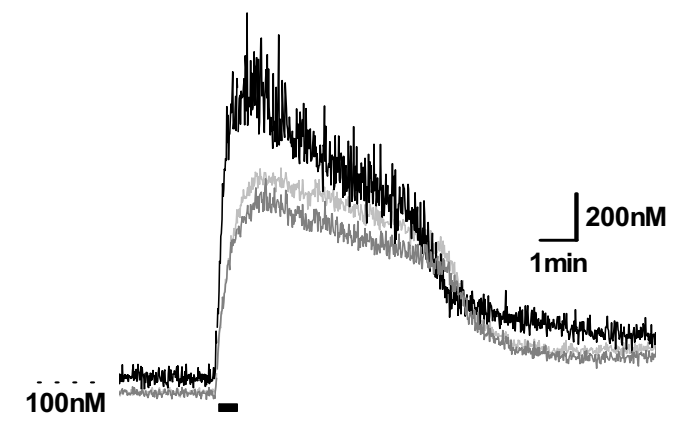

D.
NMDA

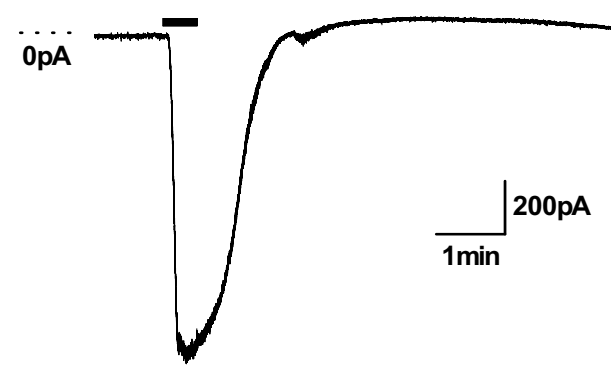

Figure 2

$\mathrm{Ca}^{2+}$ and current responses of the total extrasynaptic NMDA receptor pool in single hippocampal neurons. (A) The protocol used to isolate and measure extrasynaptic NMDA receptor responses is shown schematically. Application of 50 $\mu \mathrm{M}$ bicuculline in the presence of $10 \mu \mathrm{M}$ glycine initiates recurrent AP bursting as recorded in current clamp (IC). I0 $\mu \mathrm{M}$ MK$80 \mathrm{I}$ is then applied for 4 to 20 bursts (48 to 163 action potentials, 2 to $10 \mathrm{~min}$ ) to block synaptic NMDA receptors (synaptic blockade) before halting synaptic activity with TTX in the absence of glycine. In voltage clamp (VC, Vhold = -7I mV) the extrasynaptic pool of receptors is then activated with a $30 \mathrm{~s}$ application of $100 \mu \mathrm{M}$ NMDA in the absence of $\mathrm{Mg}^{2+}$ and the presence of $10 \mu \mathrm{M}$ glycine. Spontaneous activity of all cells was measured in cell attached mode before commencing experiments. (B-D) Example recordings from the same cell are shown for the (B) IC and (C, D) VC components of the recording. Ca ${ }^{2+}$ recordings in $\mathrm{C}$ show the isolated extrasynaptic NMDA receptor response measured in the nucleus (light grey), soma (grey) and a dendritic region $50 \mu \mathrm{m}$ from the soma (black) measured with cell impermeant bis-FURA2. 

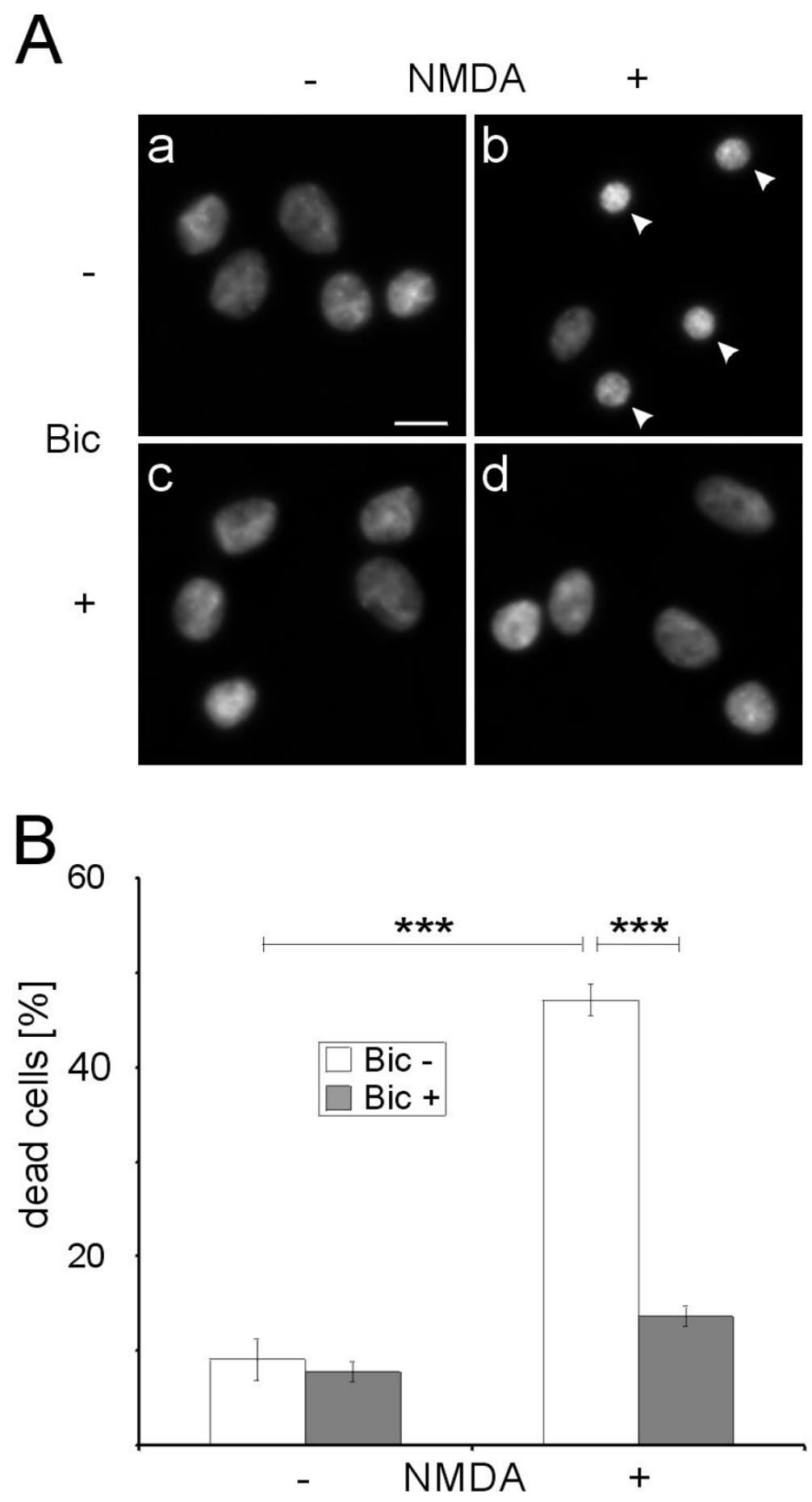

Figure 3

AP bursting protects against NMDA-induced cell death. (A) Hippocampal neurons with (+) or without (-) $16 \mathrm{~h}$ bicuculline pretreatment (Bic) were incubated with (+) or without (-) $20 \mu \mathrm{M}$ NMDA for 10 min. Five hours after NMDA washout the cells were fixed and stained with Hoechst 33258. Arrowheads indicate dead cells. Scale bar is equal to $10 \mu \mathrm{m}$. (B) Evaluation of neuronal cultures following treatment with bicuculline and NMDA showed the protective effect of bicuculline pretreatment on NMDA induced cell death. The graph represents the mean and SEM of five independent experiments. $* * * p<0.001$ independent samples t-test. 
A.

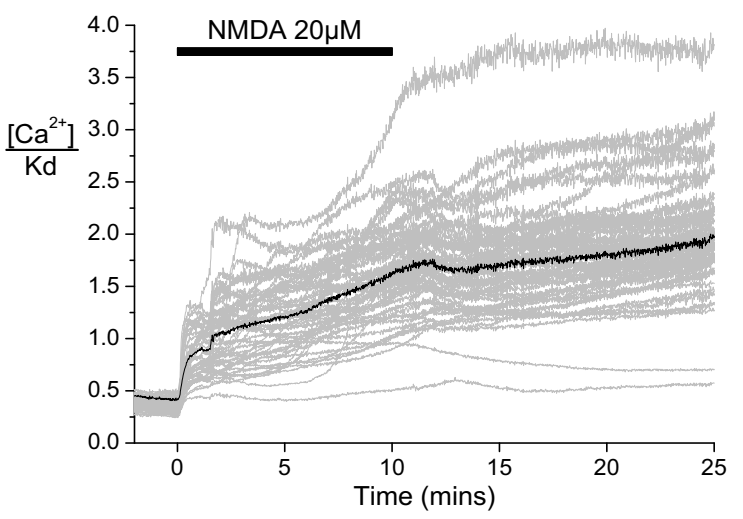

B.

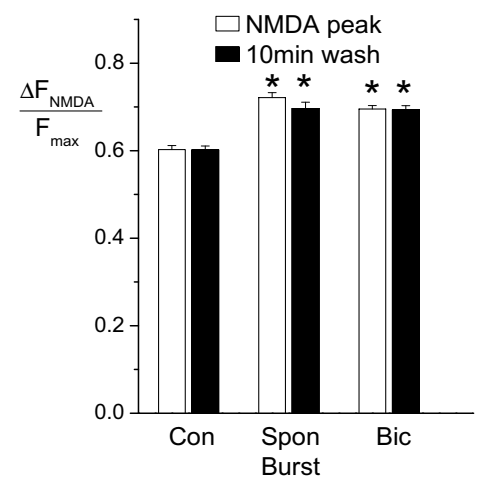

\section{Figure 4}

Imaging of $\mathrm{Ca}^{2+}$ responses to excitotoxic NMDA receptor activation. (A) Shown are representative $\mathrm{Ca}^{2+}$ responses to $20 \mu \mathrm{MNMDA}$ at $37^{\circ} \mathrm{C}$ from a representative overnight vehicle treated culture. Grey traces show the results recorded simultaneously from the soma (including nucleus) of multiple cells in the same field of view and black traces show the average of these cells. (B) Cumulative data measured at the peak of the response during NMDA application and at a point 10 min after washout of NMDA are shown from vehicle treated (Con, $n=250$ cells on 5 coverslips) spontaneously bursting (Spon Burst, $\mathrm{n}=128$ cells on 2 coverslips) and bicuculline-treated coverslips (Bic, $n=316$ cells on 6 coverslips). Peak NMDA responses and $\mathrm{Ca}^{2+}$ levels 10 min after NMDA washout in the bicuculline and spontaneously bursting groups were larger than those of the control groups ( $p<0.0 \mathrm{I}$, ANOVA, Tukey's posthoc tests).

investigate whether such changes occur after prolonged AP bursting, extrasynaptic NMDA receptor-mediated whole cell currents and $\mathrm{Ca}^{2+}$ responses were measured at room temperature in single cells (see Figure 2 and text above) from overnight vehicle and AP bursting-treated neurons. All handling and medium change was performed in parallel to equalize non-specific effects. Activity of patched cells was assessed in cell-attached mode and in current clamp mode immediately after break-in (data not shown). All neurons in the bicuculline-induced AP bursting group showed regular bursts of APs in cell-attached and/or current clamp mode as well as bursting synaptic input (bursts of spontaneous EPSCs) in voltage clamp mode. 10 to $20 \%$ of cells in the vehicle-treated group showed evidence of weak but regular bursting and were discarded from the analysis.

A number of parameters were quantified from the current and $\mathrm{Ca}^{2+}$ responses to extrasynaptic NMDA receptor stimulation (see Table 1 and Figure 5). No significant difference was seen between the AP bursting and vehicle treatment groups in any parameter including amplitude, area and half widths of either current or $\mathrm{Ca}^{2+}$ response (current: $\mathrm{n}=9$ control and 10 bicuculline treated; $\mathrm{Ca}^{2+}: \mathrm{n}$ $=5$ control and 6 bicuculline treated).

\section{Comparison of AP bursting during $M K-80 \mathrm{I}$ exposure in EPSC and bath NMDA experiments}

MK-801 is an open channel blocker requiring synchronous presynaptic glutamate release and postsynaptic depolarization to block NMDA receptors in a progressive manner over multiple synaptic activations. Although we cannot precisely quantify the number of synaptic activations in the presence of MK-801 in our recordings, we can estimate this from the number of bursts and APs occurring postsynaptically. Patch clamp and microelectrode array recordings have shown that bicuculline-induced bursts involve significant prolonged depolarization and is tightly synchronized across broad regions of the hippocampal culture [39] implying that the activity of a presynaptic and postsynaptic pair of cells is correlated and synchronized as is necessary for NMDA receptor activation. Indeed, our recordings of evoked EPSCs presented here show that synaptic NMDA receptors are rapidly blocked by our MK-801 protocol. In our recordings of bath NMDA responses we assumed that synaptic EPSCs were blocked to a similar extent to that shown in our EPSC experiments because bursting activity during MK-801 exposure was roughly equivalent to that for EPSC experiments as quantified in terms of several parameters (Table 2).

\section{Large scale analysis of extrasynaptic NMDA receptor- mediated $\mathrm{Ca}^{2+}$ responses}

Having seen no difference in extrasynaptic NMDA receptor function between vehicle and AP bursting pretreatment groups under patch clamp analysis from single cells, we wished to reinvestigate this result using larger numbers of cells. For this we used a purely imaging based assay of $\mathrm{Ca}^{2+}$ responses to extrasynaptic NMDA receptor activation in multiple cells (typically 50) in a single imaging field using a $20 \times$ objective. Cells were not voltage clamped. To counteract the effects of strong depolarization-induced activation of voltage-operated $\mathrm{Ca}^{2+}$ channels (VOCCs) 
A.
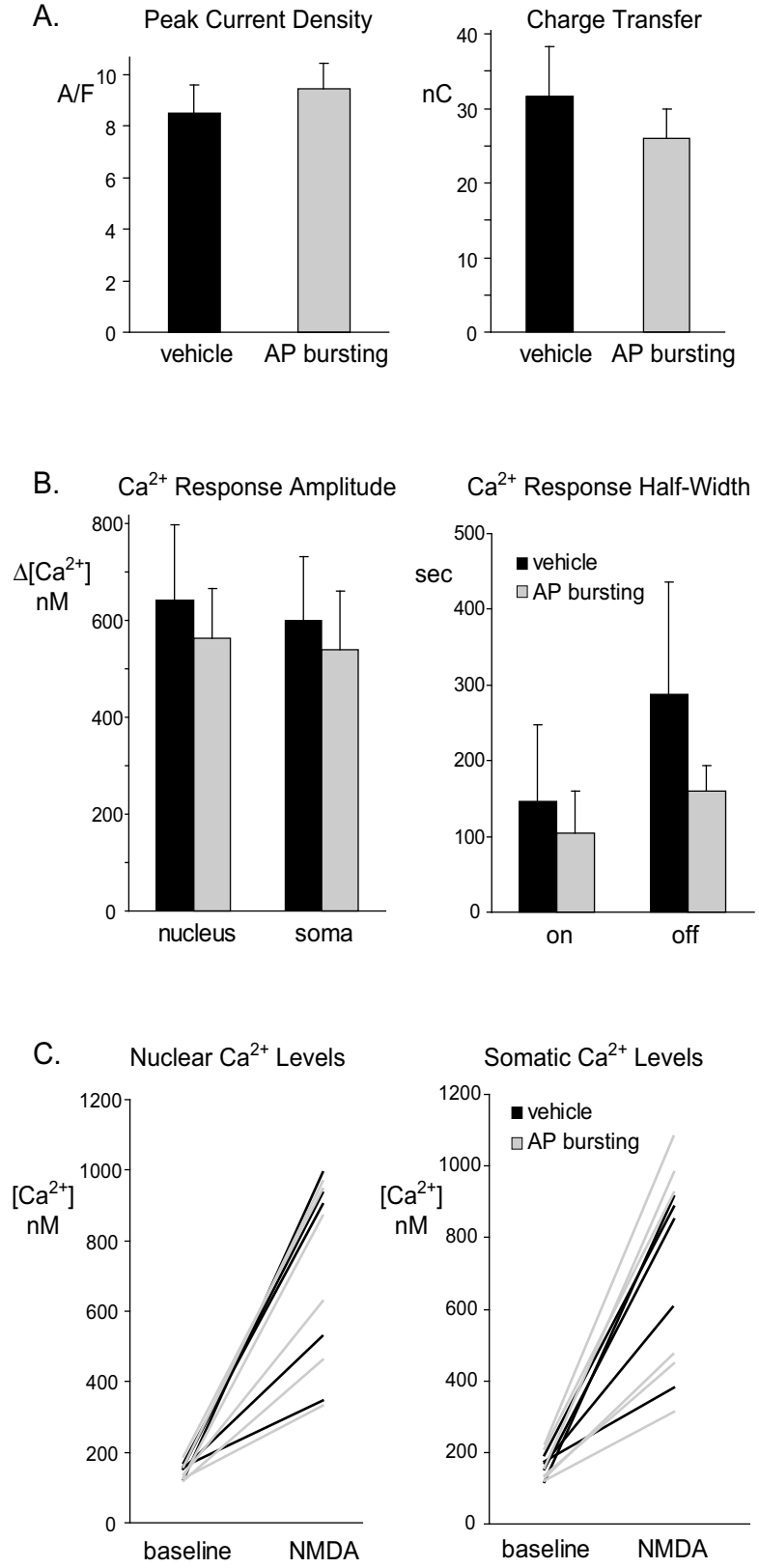

\section{Figure 5}

Cumulative data indicate no significant difference in extrasynaptic NMDA receptor-mediated current or $\mathrm{Ca}^{2+}$ responses between bicuculline and vehicle treated groups. Shown are various $(A)$ current and $(B, C) \mathrm{Ca}^{2+}$ measurement parameters from responses of neurons to bath NMDA (100 $\mu \mathrm{M})$ application following the synaptic blockade with MK$80 \mathrm{I}$ following overnight vehicle (black) and AP bursting (grey) treatment. All histograms show the mean and SEM. Electrophysiological measurements come from 9 vehicle and $10 \mathrm{AP}$ bursting treated cells. $\mathrm{Ca}^{2+}$ imaging came from 5 vehicle and $6 \mathrm{AP}$ bursting treated cells. No values were significantly different between treatment groups. (A) Peak current density was measured from the maximum macroscopic current amplitude divided by the whole cell capacitance. Charge transfer was measured from the integral of the current response with respect to baseline between response onset and return to baseline. (B) $\mathrm{Ca}^{2+}$ response amplitudes were measured with respect to baseline levels. $\mathrm{Ca}^{2+}$ response half width was calculated for the whole cell current measured from the left (on) and right (off) half of the response waveform with respect to the time point of the response peak at a level half way between baseline and response peak. (C) Nuclear and somatic $\mathrm{Ca}^{2+}$ concentrations at baseline and the NMDA response peak are shown for individual cells whereby each line connects values measured from the same cell. 
Table I: Current and $\mathrm{Ca}^{2+}$ responses in the vehicle and AP bursting groups were equivalent.

\begin{tabular}{|c|c|c|c|c|c|}
\hline & & & vehicle & AP bursting & $P$ value \\
\hline \multirow[t]{7}{*}{ Current } & peak current & $\mathrm{pA}$ & $607 \pm 110$ & $585 \pm 82$ & 0.83 \\
\hline & peak current density & $\mathrm{pA} / \mathrm{pS}$ & $8.49 \pm 1.08$ & $9.41 \pm 1.00$ & 0.54 \\
\hline & charge transfer & $\mathrm{nC}$ & $31.67 \pm 6.60$ & $25.95 \pm 4.77$ & 0.49 \\
\hline & $\tau$ on & $s$ & $7.60 \pm 1.14$ & $8.21 \pm 1.24$ & 0.72 \\
\hline & $\tau$ off & s & $19.64 \pm 3.49$ & $16.92 \pm 2.76$ & 0.54 \\
\hline & left half width & $s$ & $31.79 \pm 3.73$ & $39.27 \pm 3.47$ & 0.16 \\
\hline & right half width & s & $78.72 \pm 13.94$ & $77.15 \pm 10.73$ & 0.93 \\
\hline \multirow[t]{5}{*}{$\mathrm{Ca}^{2+}$} & peak $\mathrm{Ca}^{2+}$ & $\mathrm{nM}$ & $600 \pm 133$ & $540 \pm 121$ & 0.75 \\
\hline & $\mathrm{Ca}^{2+} 10$ min later & $\mathrm{nM}$ & $270 \pm 179$ & $|49 \pm 5|$ & 0.46 \\
\hline & $\mathrm{Ca}^{2+} \mathrm{AUC}$ & nM.s & $211 \pm 79$ & $152 \pm 38$ & 0.46 \\
\hline & left half width & s & $147 \pm 101$ & $105 \pm 55$ & 0.70 \\
\hline & right half width & $s$ & $287 \pm 150$ & $159 \pm 34$ & 0.34 \\
\hline
\end{tabular}

Charge transfer and area under the curve (AUC) were calculated from the integral of the trace between the current response onset and return to baseline and between the $\mathrm{Ca}^{2+}$ response onset and a point 10 min later. Current data comes from 9 vehicle and 10 AP bursting neurons of which $\mathrm{Ca}^{2+}$ data was recorded in 5 vehicle and $6 \mathrm{AP}$ bursting cells. All $\mathrm{Ca}^{2+}$ analysis was performed from a somatic region of interest.

and AP-induced neurotransmitter release during NMDA exposure, we included the L-type VOCC blocker, nifedipine $(10 \mu \mathrm{M})$, and the $\mathrm{Na}^{+}$channel blocker, tetrodotoxin $(1 \mu \mathrm{M})$ in our solutions. As with previous experiments, MK-801 $(10 \mu \mathrm{M})$ was applied to cells once synchronized bursting was induced with bicuculline, as seen by the regular synchronized $\mathrm{Ca}^{2+}$ oscillations in all cells (Figure $6 \mathrm{~A}, \mathrm{~B})$. Between 8 and 12 bursts were allowed to occur in the presence of MK-801 to ensure synaptic blockade. MK801 was then washed out in the presence of TTX and the absence of glycine before $\mathrm{Mg}^{2+}$-free solutions were applied followed by NMDA $(100 \mu \mathrm{M})$ for $1 \mathrm{~min}$. Due to the absence of $\mathrm{Mg}^{2+}$, this protocol induced much stronger $\mathrm{Ca}^{2+}$ responses than $10 \mathrm{~min}$ of $20 \mu \mathrm{M}$ NMDA application (see Figure 4) despite the blockade of VOCCs and APs. The responses were marginally smaller in bicucullinetreated and spontaneously bursting hippocampal neurons in comparison to the control group (control: $\mathrm{n}=261$ cells on 5 coverslips, spontaneous bursting: $\mathrm{n}=225$ cells on 4 coverslips, bicuculline: $\mathrm{n}=258$ cells on 5 coverslips, $\mathrm{p}<$ 0.0001 , Figure 6C). This result using hundreds of cells exposed a slight difference in extrasynaptic NMDA recep- tor function between treatment groups which was too small to detect with our voltage clamp analysis.

\section{Discussion}

Validation of the bicuculline $+M K-80$ I protocol to isolate extrasynaptic NMDA receptor function

In the presence of MK-801, NMDA receptors show a stepwise blockade in response to repeated synaptic activation. More than $90 \%$ blockade of synaptic receptors has been demonstrated in autaptic cultures after as few as 15 stimulations in $20 \mu \mathrm{M}$ MK-801 [38] or 60 stimuli in $5 \mu \mathrm{M} \mathrm{MK}$ 801 [45] and similar blockade is seen in cortical brain slices after 30 stimulations in $40 \mu \mathrm{M}$ MK-801 [46]. The rate of blockade will depend on the probability of transmitter release, the postsynaptic membrane potential, the concentrations of MK-801 and glycine and the rate of insertion of any new NMDA receptors into the synapses.

Our recordings of evoked synaptic NMDA EPSCs showed an $80 \%$ blockade after 4 min of MK-801 exposure during which 5 to 6 network bursts occurred. A similar degree of blockade after 2 min of the MK-801 protocol has been

Table 2: Comparison of burst properties during MK-80I exposure in experiments measuring NMDA receptor-mediated EPSCs (EPSC) and those measuring whole cell current responses to bath NMDA after EPSC blockade (Extrasynaptic).

\begin{tabular}{llll}
\hline Experiment Type & & EPSC & Extrasynaptic \\
\hline $\mathrm{n}$ & & 5 & 19 \\
incubation time & $\mathrm{min}$ & $4.5 \pm 0.7$ & $4.9 \pm 0.5$ \\
number of bursts & & $6.6 \pm 1.4$ & $106 \pm 34$ \\
number of spikes & & $-60.9 \pm 4.7$ & $97 \pm 13$ \\
RMP & $\mathrm{mV}$ & $-50.0 \pm 2.0$ & $-58.2 \pm 1.7$ \\
Vm during bursts & $\mathrm{mV}$ & $202.4 \pm 73.6$ & $-53.7 \pm 2.0$ \\
depolarisation & $\mathrm{V} . \mathrm{s}$ & & $187.6 \pm 34.6$
\end{tabular}

Average membrane potential $(V \mathrm{~m})$ during bursts was calculated from the burst onset till the return to the baseline resting membrane potential (RMP). Depolarization was calculated from the integral of the membrane potential above RMP over this same period summed across all bursts for each cell. 

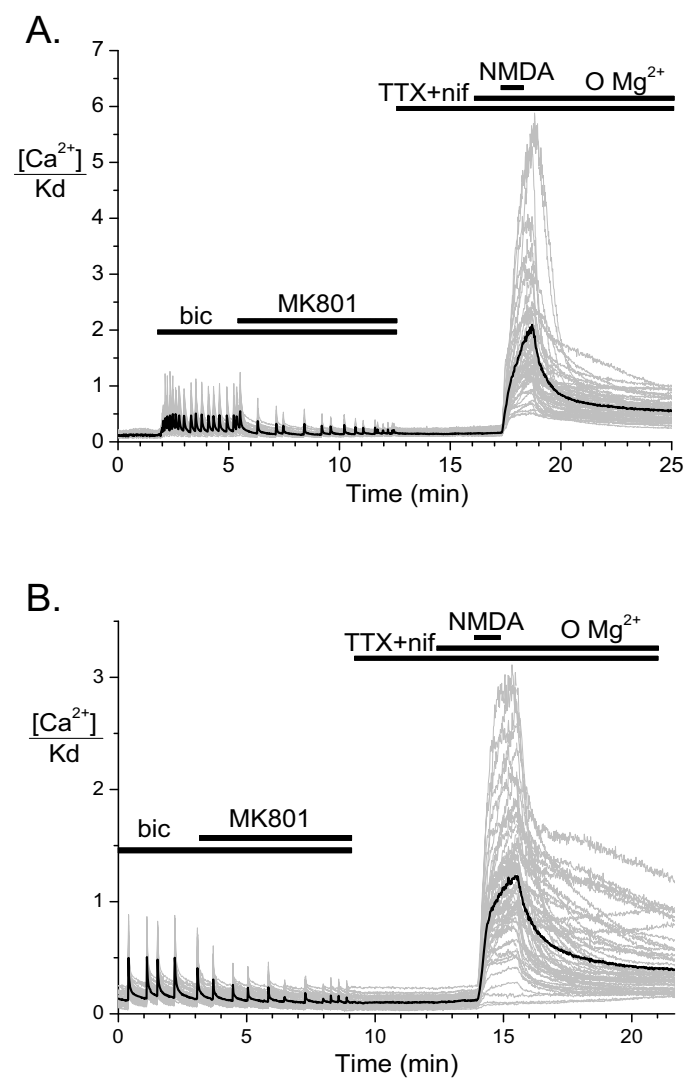

C.

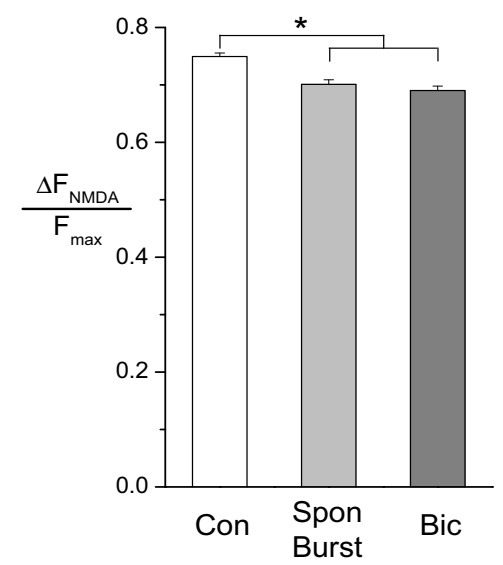

\section{Figure 6}

Imaging of $\mathrm{Ca}^{2+}$ responses to whole cell extrasynaptic NMDA receptor activation. $\mathrm{Ca}^{2+}$ responses were measured in cells loaded with X-Rhod I-AM using the same protocol shown in Figure 2A except $10 \mu M$ nifedipine (nif) was included in the TTX containing solution. (A) Representative recording from a coverslip following overnight vehicle treatment. (B) Representative recording from a coverslip following overnight AP bursting. Grey traces show the results recorded simultaneously from the soma (including nucleus) of multiple cells in the same field of view and black traces show the average of these cells. (C) Cumulative data are shown from vehicle treated non bursting coverslips (Con, $n=26$ I cells on 5 coverslips), vehicle treated coverslips showing spontaneous bursting events (Spon Burst, $n=225$ cells on 4 coverslips) and bicuculline-treated coverslips, all of which showed synchronous rhythmic AP bursting (Bic, $n=258$ cells on 5 coverslips). The peak of the NMDA response is normalized to the response to ionomycin (Fmax) in the same cell. Bars represent the mean and whiskers the SEM. The vehicle treated group was significantly different from the other two groups ( $*^{*}<0.000$ I, ANOVA, Tukey's posthoc tests). 
previously reported [13]. While further bursting may have produced a more complete blockade of synaptic NMDA receptors, it is necessary to limit the period of MK-801 application due to the presumed ongoing exchange of synaptic and extrasynaptic NMDA receptors through lateral movement [38]. Such exchange is likely to add blocked receptors to the extrasynaptic receptor population and may prevent complete blockade of synaptic responses due to the continuous immigration of unblocked NMDA receptors into the synapse. The use of 4 -aminopyridine to enhance bursting [40] could potentially avoid this problem by accelerating synaptic blockade. Higher concentrations of MK-801 are not recommended as they sometimes block burst activity in our cultures just as NMDA receptor antagonists can shut off rhythmic bursting in slices [47] and reduce synaptically-activated spikes in the hippocampus in vivo [for example [48]]. Alternatively, it remains possible that the residual $20 \%$ of EPSCs not blocked by the MK-801 and bicuculline protocol represent NMDA receptor-containing synapses which were not activated by bicucullineinduced AP bursting. A similar percentage of neurons in bicuculline-treated cultures did not show bursting in cellattached and whole cell current clamp modes. Note that residual unblocked synaptic receptors will contribute to our estimates of the extrasynaptic pool of NMDA receptors. Considering that the synaptic pool represents about $50 \%$ of the total NMDA receptor pool based on estimates from similar hippocampal cultures [13], this implies that $17 \%$ of our estimate of extrasynaptic function may be generated by synaptic receptors. Our protocol effectively isolates the extrasynaptic NMDA receptor function in standard hippocampal neuronal cultures and is a robust method to selectively activate or quantify this receptor population. This can serve as a valuable tool to study extrasynaptic NMDA receptor function in vitro as we have done here to explore the involvement of trafficking in the protective effects of synaptic activity.

\section{Overnight recurrent AP bursting only marginally alters extrasynaptic NMDA receptor function}

The only significant difference found in extrasynaptic NMDA receptor function between vehicle and overnight bursting treatment groups was a slightly smaller $\mathrm{Ca}^{2+}$ response in the latter. The $6 \%$ difference between these groups was highly significant but seems unlikely to account for the dramatic reduction in cell death afforded by pretreating cells with overnight bursting. However, we cannot rule out the possibility that a critical threshold for toxicity exists and that this $6 \%$ difference in extrasynaptic receptor function straddles this threshold to produce a dramatic difference in cell death between control and AP bursting groups. However, it seems more likely that mechanisms other than reduced extrasynaptic NMDA receptor function - such as $\mathrm{Ca}^{2+}$ regulation of survival-promoting genes [7] - are primarily responsible for the protective effects of synaptic NMDA receptor stimulation with overnight AP bursting treatment. Our observation that extrasynaptic NMDA receptor numbers are only marginally affected by prolonged increases in synaptic activity parallel reports showing that extrasynaptic NMDA receptors in contrast to synaptic receptors are unaffected by prolonged depression of synaptic activity with ethanol [49].

Other potential mechanisms for activity-induced neuroprotection include an enhanced ability of pre-treated neurons to cope with a normally toxic $\mathrm{Ca}^{2+}$ load during NMDA treatment. Regular transient $\mathrm{Ca}^{2+}$ influx associated with AP bursting for an extended period might be expected to foster improved $\mathrm{Ca}^{2+}$ buffering, sequestration, or extrusion mechanisms in neurons. To the contrary, however, the normally toxic 10 min NMDA application produced a slightly higher average $\mathrm{Ca}^{2+}$ response in hippocampal neurons treated with overnight AP bursting (see Figure 4B). Thus prolonged AP bursting does not seem to promote neuroprotection by improving the dissipation of a toxic $\mathrm{Ca}^{2+}$ load.

It is possible that the relative contribution of synaptic and extrasynaptic NMDA receptors to the $\mathrm{Ca}^{2+}$ load activated by an NMDA insult determines its toxicity and that the relative contribution of these two receptor populations is altered by activity. The $\mathrm{Ca}^{2+}$ response to bath applied NMDA arises from a mixed source including both synaptic and extrasynaptic NMDA receptor populations and VOCCs, which differentially couple to CREB function and mitochondrial membrane potential breakdown $[4,20]$. The larger $\mathrm{Ca}^{2+}$ transients in cells pretreated with AP bursting (see Figure 4B) may result from an enhanced survivalpromoting synaptic NMDA receptor component, which more than compensates for the observed slightly reduced extrasynaptic NMDA receptor function in this group. NMDA receptor exocytosis and synaptic function can be up-regulated by synaptic activity leading to long-term potentiation [50,51]. AP bursting in hippocampal cultures also potentiates synaptic transmission [39]. Any enhancement of synaptic NMDA receptor number or function should promote the protective effect of this receptor population.

It remains possible that overnight bursting accelerates the development of spines and synapses containing NMDA receptors thus increasing the synaptic NMDA receptor pool in a given neuron. $\mathrm{Ca}^{2+}$ signaling from synaptic NMDA receptors is known to enhance dendritic outgrowth [52] and synaptic delivery of NMDA receptors occurs within hours of synaptic activation [53-55]. This scenario predicts an increase in the total (synaptic plus extrasynaptic) NMDA receptor pool consistent with the slightly higher $\mathrm{Ca}^{2+}$ response to bath applied NMDA in 
cultures exposed to overnight AP bursting (see Figure 4B). The sprouting and/or growth of new NMDA receptor-containing synapses would also strengthen the relative contribution of synaptic receptors to the response to bath applied NMDA. This would help counteract the extrasynaptic NMDA receptor-mediated toxic effects and facilitate neuroprotection in cultures treated with overnight AP bursting. Regardless of any (minor) alteration in surface expression or distribution of NMDA receptors, the opposition of synaptic activity to NMDA receptor-mediated death converges at a level downstream of the receptor, through opposing effects on CREB function and target gene activation $[2,4,7]$.

\section{Conclusion}

We have developed and validated a technique for the isolation and quantitative functional assessment of the extrasynaptic NMDA receptor pool in cultured hippocampal neurons participating in neuronal networks. With this method we have shown that prolonged periods of AP bursting, which protects neurons from subsequent toxic insults, causes little change in the function of the extrasynaptic NMDA receptor pool, a receptor population linked to neuron death.

\section{Methods}

\section{Hippocampal Cell Culture}

Hippocampal neurons from new-born Sprague Dawley rats were prepared as described [56] except that growth media was supplemented with B27 (Gibco/BRL or Invitrogen, San Diego, CA) 3\% rat serum and $1 \mathrm{mM}$ glutamine. Neurons were plated onto $12 \mathrm{~mm}$ glass coverslips or plastic 4-well dishes at a density between 400 and 600 cells per $\mathrm{mm}^{2}$. All stimulations and recordings were done after a culturing period of 10 to 12 days during which hippocampal neurons develop a rich network of processes, express functional NMDA-type and AMPA/kainate-type glutamate receptors, and form synaptic contacts $[3,4,57]$.

The induction of network bursting and the cell death assay Bursts of AP firing throughout the neuronal network was induced by treatment of the neurons with $50 \mu \mathrm{M}$ bicuculline [3,39]. Bicuculline was dissolved in DMSO which did not exceed a final concentration of $0.05 \%$. Cells with or without $16 \mathrm{~h}$ bicuculline pretreatment were subjected to $20 \mu \mathrm{M} \mathrm{NMDA}$ for $10 \mathrm{~min}$ at $37^{\circ} \mathrm{C}$ to induce cell death. After washout of NMDA cells were incubated for a further $5 \mathrm{~h}$ at $37^{\circ} \mathrm{C}$ before fixation with paraformaldehyde (4\%) and stained with Hoechst 33528. Cell death was evaluated at a light microscope (Leica DM IRBE) with $40 \times$ magnification by counting condensed nuclei in 20 fields of view for every condition in each experiment. Pictures of representative areas were taken with a CCD camera (Spot Insight2; Visitron Systems, Puchheim, Germany).

\section{Patch clamp recordings}

Whole-cell patch clamp recordings were made from cultured hippocampal neurons plated on coverslips secured with a platinum ring in a recording chamber (PM-1, Warner Instruments, Hamden, CT, USA) mounted on a fixed-stage upright microscope (BX51WI, Olympus, Hamburg, Germany). Differential interference contrast optics, infrared illumination and a CCD camera (Photometrics Coolsnap HQ, Visitron Systems, Puchheim, Germany) were used to view neurons on a computer monitor using a software interface (Metamorph, Universal Imaging Systems, Downington PA, USA).

The standard extracellular solution contained (in $\mathrm{mM}$ ) $\mathrm{NaCl} 140, \mathrm{KCl} 5.3, \mathrm{MgCl}_{2} 1, \mathrm{CaCl}_{2}$ 2, HEPES 10, glycine 0.01 , glucose 30, Na-pyruvate 0.5 . Patch electrodes (3-4 $\mathrm{M} \Omega$ ) were made from borosilicate glass $(1.5 \mathrm{~mm}$, WPI, Sarasota, FL, USA) and filled with a potassium methylsulphate based intracellular solution (containing in $\mathrm{mM}$ : $\mathrm{KCH}_{3} \mathrm{SO}_{4}, 135 ; \mathrm{NaCl}, 8$; $\mathrm{KCl}, 12$; HEPES, 10; $\mathrm{K}_{2}$-phosphocreatine, $10 ; \mathrm{Mg}_{2}$-ATP, $4 ; \mathrm{Na}_{3}-\mathrm{GTP}, 0.3 ; \mathrm{pH} 7.35$ with $\mathrm{KOH})$. Recordings were made with a Multiclamp 700B amplifier, digitized through a Digidata 1322A A/D converter, acquired and analysed using pClamp software (Axon Instruments, Union City, CA, USA). Access (range: 10 - $28 \mathrm{M} \Omega$ ) was monitored regularly during voltage clamp recordings and data was rejected if changes greater than $20 \%$ occurred. All membrane potentials have been corrected for the calculated junction potential of $-11 \mathrm{mV}$ (JPCalc program by Dr. Peter H. Barry).

\section{Measurement of NMDA receptor-mediated eEPSCs}

Synaptic NMDA receptor-mediated currents were recorded at a holding potential of $+40 \mathrm{mV}$ in the presence of $10 \mu \mathrm{M}$ glycine, $1 \mathrm{mM}$ extracellular $\mathrm{Mg}^{2+},-(-)$ bicuculline (50 $\mu \mathrm{M}$, Sigma), and 6-cyano-7-nitroquinoxaline-2, 3dione (CNQX, $10 \mu \mathrm{M}$, Tocris). In some recordings, extracellular $\mathrm{Ca}^{2+}$ concentration was reduced to $0.2 \mathrm{mM}$ to reduce $\mathrm{Ca}^{2+}$ mediated inactivation of the NMDA receptor [58]. Evoked excitatory post-synaptic currents (eEPSCs) were recorded in response to single $100 \mu$ s long constant current pulse stimuli ( 80 to $200 \mu \mathrm{A}$ ) from an A365 stimulus isolator using either a tungsten stereotrode (World Presicion Instuments, Sarasota, FL, USA) or 2 glass electrodes whose tips were positioned in contact with the tissue matrix on the surface of the coverslip, on either side of the recorded cell and at a separation of 100 to $200 \mu \mathrm{m}$.

\section{MK-80 I protocol to isolate extrasynaptic NMDA receptors}

Extrasynaptic NMDA receptor-mediated currents were recorded following blockade of synaptic NMDA receptors using MK-801 application during recurrent network bursting activity. $10 \mu \mathrm{M}$ glycine was used in all our measurements of extrasynaptic NMDA receptor function to 
minimize glycine dependent NMDA receptor desensitization [59] and does not prime cells for NMDA receptor internalization [60]. Patched neurons were held in current clamp mode and bicuculline was applied. Once regular bursting was established (2-4 min), MK-801 (10 $\mu \mathrm{M}$, Tocris Cookson Ltd, Bristol, UK) was added for a further 3-10 min of bursting activity. The MK-801/bicuculline solution was then washed out for 4-6 min with a solution containing no glycine and $1 \mu \mathrm{M}$ TTX (Tocris) to halt all action potentials and NMDA receptor activation thus preventing unblocking. The cell was then voltage clamped at $-71 \mathrm{mV}$ and a zero $\mathrm{Mg}^{2+}$ solution containing glycine $(10 \mu \mathrm{M}, 2$ mins, $6 \mathrm{ml} / \mathrm{min}$ ) was washed on for $2 \mathrm{~min}$ before bath application of NMDA $(100 \mu \mathrm{M}, 30 \mathrm{~s}, 6 \mathrm{ml} / \mathrm{min})$. Current and calcium responses were used to quantify the total functional pool of extrasynaptic NMDA receptors for each cell. NMDA current responses typically showed an initial peak followed by decay which did not reach steady state within this application period. $\mathrm{Ca}^{2+}$ responses did not reach a peak or steady state plateau within this period.

Alternatively, to test for the blockade of NMDA-receptormediated EPSCs following the MK-801/bicuculline protocol, bicuculline was not removed during the MK- 801 washout period and CNQX $(10 \mu \mathrm{M})$ was added instead of TTX. CNQX was just as rapid and effective as TTX in blocking all burst activity.

\section{Calcium Imaging}

Bis-FURA2 (125 $\mu \mathrm{M}$, Biotium, Hayward, CA, USA) was included in the recording pipette solution where indicated and allowed to perfuse the neuron intracellularly for at least $20 \mathrm{~min}$ before calcium measurements began. Excitation at 340 and $380 \mathrm{~nm}$ (bandwidth 10 and $20 \mathrm{~nm}$ respectively) was generated by a monochromator coupled to a light source with a 75W Xenon arc lamp (Optoscan and Optosource, Cairn, Faversham, UK). Emission was filtered (D510/80, Chroma technologies). Calibration was performed according to the recommendations of Williams and Fay [61] and Grynkiewicz [62] using the formulas:

$$
\begin{aligned}
& R=\frac{E m_{340}-B k g_{340}}{E m_{380}-B k g_{380}} \\
& {\left[C a^{2+}\right]=k_{d}\left(S_{f 2} / S_{B 2}\right) \frac{\left(R-R_{\min }\right)}{\left(R_{\max }-R\right)}}
\end{aligned}
$$

where $\mathrm{R}$ represents the ratio of background (Bkg) subtracted emission $(E m)$ evoked by excitation at 340 and $380 \mathrm{~nm}, k d$ represents the empirical estimate of the $k d$ for bis-FURA2 using the intracellular solution (see above) with added mixtures of $\mathrm{Ca}^{2+} /$ EGTA to give theoretical $\mathrm{Ca}^{2+}$ concentrations calculated according to Portzehl et al [63], $R_{\max }$ represents the ratio value achieved following per- fusion with $10 \mu \mathrm{M}$ ionomycin and $10 \mathrm{mM} \mathrm{Ca}^{2+}, R_{\min }$ represents the ratio following subsequent perfusion with 10 mM EGTA in nominally $\mathrm{Ca}^{2+}$-free solution, $S f_{2}$ and $S B_{2}$ represent the denominators used to calculate $R_{\max }$ and $R_{\text {min' }}$ respectively. Regions of interest used for analysis of nuclear and non-nuclear somatic compartments were set as small regions well within and without the presumed nuclear boundary respectively. The nucleus was roughly identified by its much brighter labeling with bis-FURA2 as seen in single wavelength images. For multi-cellular $\mathrm{Ca}^{2+}$ imaging experiments, cells were loaded at room temperature with membrane permeable X-Rhod1-AM $(0.3 \mu \mathrm{M}$, dissolved in pluronic acid and DMSO, final concentration $0.1 \%$ DMSO) for $40 \mathrm{~min}$ followed by at least $20 \mathrm{~min}$ after washout to allow complete de-esterification of the dye. Overnight bicuculline treated cells were maintained in bicuculline during any loading and transfer procedure. Excitation light of $574 \mathrm{~nm}$ with a bandwidth of $20 \mathrm{~nm}$ was passed through a clean-up filter (560-580 nm, Chroma Technologies) and emission light was filtered through a 590-650 nm filter (Chroma Technologies). Somatic Ca2+ levels were quantified as:

$$
\left[C a^{2+}\right] / K_{d}=\frac{\left(F-F_{\min }\right)}{\left(F_{\max }-F\right)}
$$

Where F represents the average fluorescence intensity in a somatic ROI, $\mathrm{F}_{\max }$ represents the maximal $\mathrm{F}$ after incubation in ionomycin $(50 \mu \mathrm{M}), \mathrm{F}_{\min }$ represents the minimal $\mathrm{F}$ after subsequent application of EGTA $(30 \mathrm{mM})$ or a saturated manganese solution (1:200). NMDA responses were normalized to $\mathrm{F}_{\max }$ (i.e. $\mathrm{F}_{\mathrm{NMDA}} / \mathrm{F}_{\max }$ ). All data are expressed as mean \pm standard error of the mean.

\section{Authors' contributions}

$\mathrm{CPB}$ collected all data except that of the cell death assay. CPB designed the study and drafted the manuscript. OD collected and analyzed all data in the cell death assay. HB conceived the project, assisted in its design and the drafting of the manuscript. All authors read and approved of the final manuscript.

\section{Additional material}

\section{Additional file 1}

Image of a dendrite with dendritic spines from a cultured hippocampal neuron. Confocal image (collapsed from 8 optical sections of $0.5 \mu \mathrm{m}$ thickness) of GFP in the dendrite of a cultured hippocampal neuron at DIV 12. The cultures were prepared and treated identically to those used for the other experiments in this study except that they were transfected at DIV 8 with an expression vector for eGFP. Note the abundance of spines although many show an immature morphology. The scale bar is $10 \mu \mathrm{m}$. Click here for file

[http://www.biomedcentral.com/content/supplementary/14712202-9-11-S1.pdf] 


\section{Acknowledgements}

We would like to thank Iris Bünzli-Ehret for cell culture preparations and Daniela Mauceri who provided the confocal image of spines shown in the Additional file I. We also wish to specially thank Malte Wittmann and Giles Hardingham who helped establish the protocol for the cell death assay. This work was supported by the Alexander von Humboldt-Foundation (Wolgang-Paul-Prize to H.B.), EU Project GRIPANNT, the EU Network of Excellence NeuroNE, and the Sonderforschungsbereich (SFB) 488.

\section{References}

I. Vanhoutte $\mathrm{P}$, Bading $\mathrm{H}$ : Opposing roles of synaptic and extrasynaptic NMDA receptors in neuronal calcium signalling and BDNF gene regulation. Curr Opin Neurobiol 2003/07/10 edition. 2003, | 3:366-37|.

2. Hardingham GE, Bading $\mathrm{H}$ : The $Y$ in and Yang of NMDA receptor signalling. Trends Neurosci 2003, 26:8I-89.

3. Hardingham GE, Arnold FJ, Bading H: Nuclear calcium signaling controls CREB-mediated gene expression triggered by synaptic activity. Nat Neurosci 200I, 4:26I-267.

4. Hardingham GE, Fukunaga $Y$, Bading H: Extrasynaptic NMDARs oppose synaptic NMDARs by triggering CREB shut-off and cell death pathways. Nat Neurosci 2002, 5:405-4I4.

5. Liu Y, Wong TP, Aarts M, Rooyakkers A, Liu L, Lai TW, Wu DC, Lu J, Tymianski M, Craig AM, Wang YT: NMDA receptor subunits have differential roles in mediating excitotoxic neuronal death both in vitro and in vivo. J Neurosci 2007, 27:2846-2857.

6. Papadia S, Stevenson P, Hardingham NR, Bading H, Hardingham GE: Nuclear $\mathrm{Ca} 2+$ and the cAMP response element-binding protein family mediate a late phase of activity-dependent neuroprotection. J Neurosci 2005, 25:4279-4287.

7. Zhang SJ, Steijaert MN, Lau D, Schutz G, Delucinge-Vivier C, Descombes P, Bading H: Decoding NMDA Receptor Signaling: Identification of Genomic Programs Specifying Neuronal Survival and Death. Neuron 2007, 53:549-562.

8. Eimerl S, Schramm M: The quantity of calcium that appears to induce neuronal death. J Neurochem 1994, 62:1223-1226.

9. Lu YM, Yin HZ, Chiang J, Weiss JH: Ca(2+)-permeable AMPA/ kainate and NMDA channels: high rate of $\mathrm{Ca}+$ influx underlies potent induction of injury. J Neurosci 1996, 16:5457-5465.

10. von Engelhardt J, Coserea I, Pawlak V, Fuchs EC, Kohr G, Seeburg PH, Monyer H: Excitotoxicity in vitro by NR2A- and NR2B-containing NMDA receptors. Neuropharmacology 2007, 53:10-17.

II. Kim MJ, Dunah AW, Wang YT, Sheng M: Differential roles of NR2A- and NR2B-containing NMDA receptors in Ras-ERK signaling and AMPA receptor trafficking. Neuron 2005, 46:745-760.

12. Krapivinsky G, Krapivinsky L, Manasian Y, Ivanov A, Tyzio R, Pellegrino C, Ben-Ari Y, Clapham DE, Medina I: The NMDA receptor is coupled to the ERK pathway by a direct interaction between NR2B and RasGRFI. Neuron 2003/I I//9 edition. 2003, 40:775-784.

13. Ivanov A, Pellegrino C, Rama S, Dumalska I, Salyha Y, Ben-Ari Y, Medina I: Opposing role of synaptic and extrasynaptic NMDA receptors in regulation of the extracellular signal-regulated kinases (ERK) activity in cultured rat hippocampal neurons. J Physiol 2006, 572:789-798.

14. Lee B, Butcher GQ, Hoyt KR, Impey S, Obrietan K: Activitydependent neuroprotection and CAMP response elementbinding protein (CREB): kinase coupling, stimulus intensity, and temporal regulation of CREB phosphorylation at serine 133. J Neurosci 2005, 25: I |37-I I 48.

15. Xu J, Zhang QG, Li C, Zhang GY: Subtoxic N-methyl-D-aspartate delayed neuronal death in ischemic brain injury through TrkB receptor- and calmodulin-mediated PI-3K/Akt pathway activation. Hippocampus 2007, 17:525-537.

16. Marini AM, Jiang X, Wu X, Pan H, Guo Z, Mattson MP, Blondeau N, Novelli A, Lipsky RH: Preconditioning and neurotrophins: a model for brain adaptation to seizures, ischemia and other stressful stimuli. Amino Acids 2007, 32:299-304.

17. Miao B, Yin XH, Pei DS, Zhang QG, Zhang GY: Neuroprotective effects of preconditioning ischemia on ischemic brain injury through down-regulating activation of JNKI/2 via $\mathrm{N}$-methylD-aspartate receptor-mediated Akt I activation. J Biol Chem 2005, 280:21693-21699.
18. Mabuchi T, Kitagawa K, Kuwabara K, Takasawa K, Ohtsuki T, Xia Z, Storm D, Yanagihara T, Hori M, Matsumoto M: Phosphorylation of cAMP response element-binding protein in hippocampal neurons as a protective response after exposure to glutamate in vitro and ischemia in vivo. J Neurosci 200I, 21:9204-92I3.

19. Raval AP, Dave KR, Mochly-Rosen D, Sick TJ, Perez-Pinzon MA: Epsilon $P K C$ is required for the induction of tolerance by ischemic and NMDA-mediated preconditioning in the organotypic hippocampal slice. J Neurosci 2003, 23:384-391.

20. Soriano FX, Papadia S, Hofmann F, Hardingham NR, Bading H, Hardingham GE: Preconditioning doses of NMDA promote neuroprotection by enhancing neuronal excitability. J Neurosci 2006 , 26:4509-45 I8.

21. Lancelot E, Revaud ML, Boulu RG, Plotkine M, Callebert J: A microdialysis study investigating the mechanisms of hydroxyl radical formation in rat striatum exposed to glutamate. Brain Res 1998, 809:294-296.

22. Lipton SA, Rosenberg PA: Excitatory amino acids as a final common pathway for neurologic disorders. N Engl J Med 1994, 330:613-622.

23. Fan MM, Raymond LA: N-Methyl-d-aspartate (NMDA) receptor function and excitotoxicity in Huntington's disease. Prog Neurobiol 2007, 81:272-293.

24. Kaul M, Garden GA, Lipton SA: Pathways to neuronal injury and apoptosis in HIV-associated dementia. Nature 200I, 410:988-994.

25. Lipton P: Ischemic cell death in brain neurons. Physiol Rev 1999, 79: $143 \mid-1568$.

26. Bramlett HM, Dietrich WD: Pathophysiology of cerebral ischemia and brain trauma: similarities and differences. Cereb Blood Flow Metab 2004, 24:133-150.

27. Hara MR, Snyder SH: Cell signaling and neuronal death. Annu Rev Pharmacol Toxicol 2007, 47: I 17-I4I.

28. Habas A, Kharebava G, Szatmari E, Hetman M: NMDA neuroprotection against a phosphatidylinositol-3 kinase inhibitor, LY294002 by NR2B-mediated suppression of glycogen synthase kinase-3beta-induced apoptosis. J Neurochem 2006, 96:335-348.

29. Zhu D, Wu X, Strauss KI, Lipsky RH, Qureshi Z, Terhakopian A, Novelli A, Banaudha K, Marini AM: N-methyl-D-aspartate and TrkB receptors protect neurons against glutamate excitotoxicity through an extracellular signal-regulated kinase pathway. J Neurosci Res 2005, 80:104-II3.

30. Carroll RC, Zukin RS: NMDA-receptor trafficking and targeting: implications for synaptic transmission and plasticity. Trends Neurosci 2002/I0/24 edition. 2002, 25:57/-577.

31. Watt AJ, van Rossum MC, MacLeod KM, Nelson SB, Turrigiano GG: Activity coregulates quantal AMPA and NMDA currents at neocortical synapses. Neuron 2000, 26:659-670.

32. Perez-Otano I, Lujan R, Tavalin SJ, Plomann M, Modregger J, Liu XB, Jones EG, Heinemann SF, Lo DC, Ehlers MD: Endocytosis and synaptic removal of NR3A-containing NMDA receptors by PACSINI/syndapin I. Nat Neurosci 2006, 9:6 I I-62I.

33. Groc L, Heine M, Cognet L, Brickley K, Stephenson FA, Lounis B, Choquet $D$ : Differential activity-dependent regulation of the lateral mobilities of AMPA and NMDA receptors. Nat Neurosci 2004, 7:695-696.

34. Harris AZ, Pettit DL: Extrasynaptic and synaptic NMDA receptors form stable and uniform pools in rat hippocampal slices. J Physiol 2007/08/25 edition. 2007, 584:509-519.

35. Le Meur K, Galante M, Angulo MC, Audinat E: Tonic activation of NMDA receptors by ambient glutamate of non-synaptic origin in the rat hippocampus. J Physiol 2007, 580:373-383.

36. Huettner JE, Bean BP: Block of N-methyl-D-aspartate-activated current by the anticonvulsant MK-80I: selective binding to open channels. Proc Natl Acad Sci U S A 1988, 85: | 307-|3|I.

37. Rosenmund C, Westbrook GL: Rundown of N-methyl-D-aspartate channels during whole-cell recording in rat hippocampal neurons: role of Ca2+ and ATP. J Physiol 1993, 470:705-729.

38. Tovar KR, Westbrook GL: Mobile NMDA receptors at hippocampal synapses. Neuron 2002, 34:255-264.

39. Arnold FJ, Hofmann F, Bengtson CP, Wittmann M, Vanhoutte P, Bading $\mathrm{H}$ : Microelectrode array recordings of cultured hippocampal networks reveal a simple model for transcription and protein synthesis-dependent plasticity. J Physiol 2005, 564:3-19. 
40. Hardingham GE, Bading $\mathrm{H}$ : Coupling of extrasynaptic NMDA receptors to a CREB shut-off pathway is developmentally regulated. Biochim Biophys Acta 2002, 1600: 148-153.

4I. Hartley DM, Kurth MC, Bjerkness L, Weiss JH, Choi DW: Glutamate receptor-induced $45 \mathrm{Ca} 2+$ accumulation in cortical cell culture correlates with subsequent neuronal degeneration. $J$ Neurosci 1993, I3:1993-2000.

42. Pivovarova NB, Nguyen HV, Winters CA, Brantner CA, Smith CL, Andrews SB: Excitotoxic calcium overload in a subpopulation of mitochondria triggers delayed death in hippocampal neurons. J Neurosci 2004, 24:56 I I-5622.

43. Blanpied TA, Scott DB, Ehlers MD: Dynamics and regulation of clathrin coats at specialized endocytic zones of dendrites and spines. Neuron 2002, 36:435-449.

44. Petralia RS, Wang YX, Wenthold RJ: Internalization at glutamatergic synapses during development. Eur J Neurosci 2003, 18:3207-3217.

45. Tovar KR, Westbrook GL: The incorporation of NMDA receptors with a distinct subunit composition at nascent hippocampal synapses in vitro. J Neurosci 1999, 19:4|80-4|88.

46. Yashiro K, Corlew R, Philpot BD: Visual deprivation modifies both presynaptic glutamate release and the composition of perisynaptic/extrasynaptic NMDA receptors in adult visual cortex. J Neurosci 2005, 25: I 1684-1 I692.

47. Bonansco C, Gonzalez de la Vega A, Gonzalez Alegre P, Borde M, Garca-Segura LM, Buno W: Tetanic stimulation of schaffer collaterals induces rhythmic bursts via NMDA receptor activation in rat CAI pyramidal neurons. Hippocampus 2002, I 2:434-446.

48. Abraham WC, Mason SE: Effects of the NMDA receptor/channel antagonists CPP and MK80I on hippocampal field potentials and long-term potentiation in anesthetized rats. Brain Res 1988, 462:40-46.

49. Carpenter-Hyland EP, Woodward IJ, Chandler LI: Chronic ethanol induces synaptic but not extrasynaptic targeting of NMDA receptors. J Neurosci 2004/09/10 edition. 2004, 24:7859-7868.

50. Grosshans DR, Clayton DA, Coultrap SJ, Browning MD: LTP leads to rapid surface expression of NMDA but not AMPA receptors in adult rat CAI. Nat Neurosci 2002, 5:27-33.

51. Watt AJ, Sjostrom PJ, Hausser M, Nelson SB, Turrigiano GG: A proportional but slower NMDA potentiation follows AMPA potentiation in LTP. Nat Neurosci 2004, 7:5। 8-524.

52. Wayman GA, Impey S, Marks D, Saneyoshi T, Grant WF, Derkach V, Soderling TR: Activity-dependent dendritic arborization mediated by CaM-kinase I activation and enhanced CREBdependent transcription of Wnt-2. Neuron 2006/06/15 edition. 2006, 50:897-909.

53. Rao A, Craig AM: Activity regulates the synaptic localization of the NMDA receptor in hippocampal neurons. Neuron 1997/II/ I4 edition. 1997, 19:80I-8I2.

54. Friedman HV, Bresler T, Garner CC, Ziv NE: Assembly of new individual excitatory synapses: time course and temporal order of synaptic molecule recruitment. Neuron 2000/08/12 edition. 2000, 27:57-69.

55. Liao D, Zhang X, O'Brien R, Ehlers MD, Huganir RL: Regulation of morphological postsynaptic silent synapses in developing hippocampal neurons. Nat Neurosci 1999/04/09 edition. 1999, 2:37-43.

56. Bading H, Greenberg ME: Stimulation of protein tyrosine phosphorylation by NMDA receptor activation. Science 199//08/23 edition. 1991, 253:912-914.

57. Bading H, Segal MM, Sucher NJ, Dudek H, Lipton SA, Greenberg ME: $\mathbf{N}$-methyl-D-aspartate receptors are critical for mediating the effects of glutamate on intracellular calcium concentration and immediate early gene expression in cultured hippocampal neurons. Neuroscience 1995, 64:653-664.

58. Legendre P, Rosenmund C, Westbrook GL: Inactivation of NMDA channels in cultured hippocampal neurons by intracellular calcium. J Neurosci 1993/02/0I edition. 1993, I 3:674-684.

59. Mayer ML, Vyklicky L Jr., Clements J: Regulation of NMDA receptor desensitization in mouse hippocampal neurons by glycine. Nature 1989, 338:425-427.

60. Nong Y, Huang YQ, Ju W, Kalia LV, Ahmadian G, Wang YT, Salter $\mathrm{MW}$ : Glycine binding primes NMDA receptor internalization. Nature 2003, 422:302-307.
61. Williams DA, Fay FS: Intracellular calibration of the fluorescent calcium indicator Fura-2. Cell Calcium 1990, I I:75-83.

62. Grynkiewicz G, Poenie M, Tsien RY: A new generation of Ca2+ indicators with greatly improved fluorescence properties. Biol Chem 1985, 260:3440-3450.

63. Portzehl H, Caldwell PC, Rueegg JC: The Dependence of Contraction and Relaxation of Muscle Fibres from the Crab Maia Squinado on the Internal Concentration of Free Calcium Ions. Biochim Biophys Acta 1964, 79:58I-59I.
Publish with Biomed Central and every scientist can read your work free of charge

"BioMed Central will be the most significant development for disseminating the results of biomedical research in our lifetime. "

Sir Paul Nurse, Cancer Research UK

Your research papers will be:

- available free of charge to the entire biomedical community

- peer reviewed and published immediately upon acceptance

- cited in PubMed and archived on PubMed Central

- yours - you keep the copyright
BioMedcentral 